\title{
Transplanting Depth Affects Pepper Lodging and Maturity
}

\author{
Francis X. Mangan ${ }^{1}$ \\ Department of Plant and Soil Sciences, Bowditch Hall, University of \\ Massachusetts, Amherst, MA 01003
}

Charles S. Vavrina

University of Florida, Southwest Florida Research and Education Center, P.O. Drawer 5127, Immokalee, FL 33934

\author{
John C. Howell \\ Department of Plant and Soil Sciences, Bowditch Hall, University of \\ Massachusetts, Amherst, MA 01003
}

Additional index words. Capsicum annuum, stand establishment, seedlings, fruit color

\begin{abstract}
The effects of transplant depth on lodging and yield were evaluated in five experiments in Florida and Massachusetts. 'Cherry Bomb', 'Jupiter', and 'Mitla' pepper (Capsicum annuum L.) transplants were set at three depths so that the soil surface was even with the top of the rootball, the cotyledon leaf, or the first true leaf. Seedlings set to the depth of cotyledon leaves or to the first true leaf lodged less than did those set to the top of the rootball. No yield differences were recorded among treatments in Massachusetts; however, total weight of red fruit was greater in treatments that lodged less in 1 of the 2 years, suggesting that lodging delayed maturity. Soil temperature in Massachusetts declined at the level of the rootball as planting depth increased.
\end{abstract}

Vavrina et al. (1994, 1996) found that pepper or tomato (Lycopersicon esculentum Mill.) yields were higher if seedlings were set to the first true leaf or cotyledon leaf than if set to the top of the rootball. These authors also observed that setting the transplants deeper in the soil generally hastened maturity as indicated by redder fruit.

Researchers in Oklahoma reported that paprika peppers were more prone to lodge (root, stem, or branch) if transplants were used instead of direct seeding in 1 out of 3 years; however, fruit yield was not affected (Cooksey et al., 1994). In Israel, Pinthus (1967) observed that varieties of wheat (Triticum aestivum L.) with root systems that spread more extensively in a horizontal direction were more resistant to lodging than varieties with less extensive root systems. Lodging of pepper plants can reduce yields, especially with mechanical harvesting (Kahn, 1985; McCullough et al., 1995).

Soil temperatures can affect root growth, which in turn can affect lodging. Optimum temperatures for root growth can vary among plant species. Fluctuations of soil temperatures outside the optimum range can restrict root growth (McMichael and Burke, 1998; Stoffella et al., 1979).

\footnotetext{
Received for publication 15 June 1999. Accepted for publication 16 Nov. 1999. We thank Karen Armbrester and Mickey Pena for their technical assistance in the field. The cost of publishing this paper was defrayed in part by the payment of page charges. Under postal regulations, this paper therefore must be hereby marked advertisement solely to indicate this fact.

${ }^{1}$ To whom reprint requests should be addressed.
}

The work in Massachusetts was initiated due to complaints from farmers that 'Cherry Bomb' peppers, recently introduced to Massachusetts for processing, were more prone to lodging than were the other commonly grown pepper cultivars. Lodging interfered with field operations and harvesting, either mechanically or by hand. Our original work in Florida was initiated to evaluate the effects of transplant depth on pepper growth and yield under plastic mulch. The idea arose from county agents' requests on how to handle "leggy" transplants supplied by local producers.

\section{Materials and Methods}

Massachusetts. Transplants of 'Cherry Bomb' pepper were commercially grown in Fafard (Anderson, S.C.) Germination Mix (containing sphagnum peatmoss, perlite, and vermiculite) in inverted pyramid, square 200 cells. Plants received two fertilizations per week; 300 $\mathrm{mg} \cdot \mathrm{L}^{-1}$ of $20 \mathrm{~N}-4 \mathrm{P}-17 \mathrm{~K}$ was alternated with $300 \mathrm{mg} \cdot \mathrm{L}^{-1}$ of $15 \mathrm{~N}-0 \mathrm{P}-12 \mathrm{~K}$ during transplant production. Transplants were grown in a greenhouse for 7 weeks and were $\approx 15$-cm tall in 1995 and $17 \mathrm{~cm}$ in 1996 , measured from the top of the transplant plug to the apical meristem.

The experiments were implemented at the Univ. of Massachusetts Research Farm in South Deerfield, on an Occum fine sandy loam (coarse-loamy, mixed, mesic Fluventic Dystrochrept) with a $\mathrm{pH}$ of 7.0 and a soil organic matter content of $2.7 \%$.

Fertilizer (in kg.ha ${ }^{-1}$ ) of $20 \mathrm{P}$ and $54 \mathrm{~K}$ in 1995 and $0 \mathrm{P}$ and $75 \mathrm{~K}$ in 1996 was soil incorporated based on Univ. of Massachusetts recommendations from soil test results. Pepper plants were transplanted on 12 June 1995 and 11 June 1996 to three different depths corresponding to the following parts of the seedling: top of the rootball, base of cotyledon leaf, and first true leaf. Commercial transplants from Massachusetts and Florida differed in size; therefore, anatomical designations were used as the planting depth determinant rather than measured distances above the rootball.

Plant spacing was $30 \mathrm{~cm}$ in the row and 90 $\mathrm{cm}$ between rows for a plant population of 36,000 plants/ha. Plants were grown on bare ground with three rows per plot. A starter solution of $250 \mathrm{~mL}$ (made of $15 \mathrm{~mL}$ of $10 \mathrm{~N}-$ $13 \mathrm{P}-17 \mathrm{~K}$ in $3.8 \mathrm{~L}$ of water) was applied to each transplant. Nitrogen was applied as ammonium nitrate in two applications. In 1995, $56 \mathrm{~kg} \cdot \mathrm{ha}^{-1} \mathrm{~N}$ was applied on $14 \mathrm{June}$ and again on 30 July. In 1996, $56 \mathrm{~kg} \cdot \mathrm{ha}^{-1} \mathrm{~N}$ was applied on 12 June and $112 \mathrm{~kg} \cdot \mathrm{ha}^{-1}$ on 28 July. Weeds were controlled by hand cultivation during the growing season. No insecticides or fungicides were applied.

Lodging data were taken on the middle 10 plants in the center row once per week beginning 1 week after transplanting and ending shortly before harvest. A plant was considered to be lodged if it was leaning at a $45^{\circ}$ angle or more from the perpendicular (Pinthus, 1967).

Temperature probes (Fisher Scientific, Ottawa, Can.) were placed at three depths between rows, corresponding to the approximate depths of the rootball for the three treatments at 2,7 , or $12 \mathrm{~cm}$ below the soil surface. Readings were taken at 1:00 PM on two dates in 1995 and three dates in 1996. For each date, ambient temperatures and percentage of cloud cover were recorded.

Plants were harvested on 30 Aug. 1995 and 3 Sept. 1996. Plants grew in the field for $80 \mathrm{~d}$ in 1995 and $84 \mathrm{~d}$ in 1996. For each harvest date, all fruit were removed from the middle 10 plants of the center row, counted, and weighed. Red fruit were counted and weighed separately. A fruit was considered red if more than $50 \%$ of the surface by visual indexing had turned red.

Florida. Pepper transplants were commercially grown in Heco plug mix (Southern Importers, Greensboro, N.C.) in $26-\mathrm{cm}^{3}$ inverted pyramid containerized (200) cells (Speedling, Plant City, Fla.). Plants were grown in greenhouses under natural light and seasonal temperature for 5 to 6 weeks. They received $375 \mathrm{mg} \cdot \mathrm{L}^{-1}$ of $20 \mathrm{~N}-4 \mathrm{P}-17 \mathrm{~K}$ daily. Plant height was 14 to $16 \mathrm{~cm}$, measured from the top of the transplant plug to the apical meristem.

'Jupiter' (Rogers Seed, Boise, Idaho) bell pepper transplants were planted on 13 Feb. and 15 Sept. 1992 and 'Mitla' (Petoseed, Saticoy, Calif.) jalapeno pepper transplants were planted on 6 Feb. 1997 in Immokalee, Fla., to the same three depths used in Massachusetts: top of the rootball, to the base of the cotyledon leaves, or to the first true leaf. Lodging was assessed on selected dates for each experiment using the same criteria as in Massachusetts. Lodging was not the intent of the Florida trials (stand establishment and yield), but was noted as ancillary information, there- 
fore a rigid sampling schedule was not used. In the jalapeno trial, lodging was the intent, so data recording began when lodging began and ended when the count stabilized.

Plants in Immokalee (Immokalee fine sand-sandy, silacaceous, hyperthermic, Arenic Haplaquod) were transplanted into raised beds $(20 \mathrm{~cm})$ on $1.8-\mathrm{m}$ centers, two rows per bed, with $25 \mathrm{~cm}$ between rows and between plants $\left(5.6 \mathrm{~m}^{2}\right.$ per replication $)$. The Immokalee crops received (in kg.ha ${ }^{-1}$ ) $224 \mathrm{~N}$, $291 \mathrm{~K}$, and $56 \mathrm{P}$ in fall, $78 \mathrm{P}$ in spring by soil test plus basic micronutrients, all placed under the plastic mulch at planting. In applying this fertilizer, $67 \mathrm{~kg} \cdot \mathrm{ha}^{-1}$ each of $\mathrm{N}$ and $\mathrm{K}$ and all the $\mathrm{P}$ and micronutrients were broadcast on flat ground and then covered by a soil bed 12 to $15 \mathrm{~cm}$ deep. The remaining $\mathrm{N}$ and $\mathrm{K}$ were applied after bed formation in two narrow bands on top of the bed, $32 \mathrm{~cm}$ on each side of the bed crown. The soil was simultaneously fumigated with $98 \%$ methyl bromide : $2 \%$ chloropicrin at $314 \mathrm{~kg} \cdot \mathrm{ha}^{-1}$ while the final bed was shaped. The beds were then covered with 0.03 -mm polyethylene mulch (black in spring, white in fall). Subsurface seepage irrigation was employed to maintain a constant water table level $60 \mathrm{~cm}$ below the bed. Fungicides and insecticides were applied as needed, based on recommendations of the Univ. of Florida.

A randomized complete-block design was used in all experiments with four replications in Massachusetts and six replications in Florida. All data were analyzed by analysis of variance, using Duncan's multiple range test at $P \leq 0.05$ for mean separation.

\section{Results and Discussion}

In Massachusetts, plants transplanted to the top of the rootball lodged more readily than those set to the first true leaf or to the cotyledon (Table 1). In 1995, differences in lodging occurred each week, whereas in 1996, no plant lodging was observed in any treatment until week 4 , with no statistical difference in lodging being noted until week 8 .

Weather may have played a role in the increased lodging observed. In 1995, high winds occurred on 15 July, which may have increased lodging between weeks 4 and 5. A thunderstorm with gusty winds and $1.3 \mathrm{~cm}$ of rain occurred on 23 July, which may have led to the increase in lodging observed between weeks 6 and 7. In 1996, a storm with $3.8 \mathrm{~cm}$ of rain on 3 July may have caused the onset of lodging on week 4 . Heavy rains fell on 13 July $(8.6 \mathrm{~cm})$ and 26 July $(4.2 \mathrm{~cm})$, creating saturated soils; this, combined with increasing fruit loads, may have led to the dramatic increase in lodging observed on week 8 .

In Florida, more plants lodged when planted to the top of the rootball than to the cotyledon or to the first true leaf in each of three separate plantings (Table 2). No lodging was observed on any dates for plants transplanted to the true leaf.

No differences were observed in total yield among treatments in either year in Massachusetts (data not shown). In 1995, the weight of red fruit was less in peppers transplanted to the rootball than to the cotyledon leaf or to the first true leaf (Table 1). Previous work with tomato has demonstrated that increased lodging of plants can delay fruit maturity (Vavrina et al., 1996).

In general, bell pepper yield increased with planting depth in both Florida experiments in 1992 (Vavrina et al., 1994). The jalapeno study was undertaken solely to develop data on lodging, so harvest data were not taken.

Soil temperatures at 2 and $7 \mathrm{~cm}$ below the soil surface were higher than at $12 \mathrm{~cm}$ at 1:00 PM on four of the five dates for which readings were taken in Massachusetts (Table 3). The temperature differences were less on cloudy days (all three dates in 1996), and no differences were detected on 19 June 1996, with $100 \%$ cloud cover. Researchers in Louisiana recorded lower soil temperatures at $15 \mathrm{~cm}$ below the soil surface than at $7.5 \mathrm{~cm}$, corresponding to the rootball depths of tomato transplants (Hanna et al., 1997). They specu-

lated that shallow planting may have reduced root growth because of high soil temperatures. McMichael and Burke (1998) listed 18 plant species with optimum temperatures for root growth ranging from $17 \%$ to $35^{\circ} \mathrm{C}$. The temperature observed at $2 \mathrm{~cm}$ below the soil surface on 13 Aug. $1995\left(40^{\circ} \mathrm{C}\right)$ was above this range. This suggests that high temperatures may have limited root growth in plants transplanted to the top of the rootball. Stoffella et al. (1979) and Kahn (1985) observed that vegetable plants with greater root weights were less likely to lodge.

Precipitation during the season measured $14.9 \mathrm{~cm}$ in 1995 compared with $38.9 \mathrm{~cm}$ in 1996. The 40-year average for this area and time period is $29.5 \mathrm{~cm}$ The dry soil conditions in 1995 may have retarded root growth, which may account for the earlier onset and more intense lodging observed in 1995 than in 1996.

In addition to the effects that weather and soil temperatures may have had on lodging,

Table 1. Pepper plant lodging and fruit color as affected by transplant depth in 1995 and 1996 in Massachusetts.

\begin{tabular}{|c|c|c|c|c|c|c|c|c|c|c|c|}
\hline \multirow[b]{3}{*}{ Depth } & \multicolumn{9}{|c|}{ Plants lodged $(\%)$} & \multirow{2}{*}{\multicolumn{2}{|c|}{ Red fruit $(\%)$}} \\
\hline & \multicolumn{9}{|c|}{ Weeks after transplanting } & & \\
\hline & 1 & 2 & 3 & 4 & 5 & 6 & 7 & 8 & 9 & By no. & $\overline{\text { By wt }}$ \\
\hline \multicolumn{12}{|c|}{1995} \\
\hline Rootball & $26 \mathrm{a}^{2}$ & 26 a & $29 \mathrm{a}$ & $31 \mathrm{a}$ & 39 a & $68 \mathrm{a}$ & $80 \mathrm{a}$ & $83 \mathrm{a}$ & $83 \mathrm{a}$ & 6.6 & $9.5 \mathrm{a}$ \\
\hline Cotyledon & $0 \mathrm{~b}$ & $8 \mathrm{~b}$ & $8 a b$ & $8 \mathrm{~b}$ & $19 \mathrm{~b}$ & $24 \mathrm{~b}$ & $31 \mathrm{~b}$ & $31 \mathrm{~b}$ & $34 \mathrm{~b}$ & 9.3 & $15.2 \mathrm{~b}$ \\
\hline True Leaf & $0 \mathrm{~b}$ & $6 \mathrm{~b}$ & $6 \mathrm{~b}$ & $6 \mathrm{~b}$ & $8 \mathrm{~b}$ & $11 \mathrm{~b}$ & $11 \mathrm{~b}$ & $11 \mathrm{~b}$ & $11 \mathrm{~b}$ & 9.1 & $13.2 \mathrm{~b}$ \\
\hline Significance & ** & $*$ & $*$ & $*$ & $*$ & $*$ & $* *$ & $* *$ & $* *$ & NS & $*$ \\
\hline \multicolumn{12}{|c|}{1996} \\
\hline Rootball & 0 & 0 & 0 & 5 & 20 & 20 & 20 & $63 \mathrm{a}$ & $65 \mathrm{a}$ & 11.2 & 18.1 \\
\hline Cotyledon & 0 & 0 & 0 & 8 & 10 & 10 & 10 & $35 \mathrm{~b}$ & $37 \mathrm{~b}$ & 12.8 & 16.0 \\
\hline True Leaf & 0 & 0 & 0 & 5 & 5 & 8 & 8 & $10 \mathrm{c}$ & $13 \mathrm{c}$ & 9.8 & 14.5 \\
\hline Significance & NS & NS & NS & NS & NS & NS & NS & $* *$ & ** & NS & NS \\
\hline
\end{tabular}

${ }^{2}$ Mean separation within columns and years by Duncan's multiple range test at $P \leq 0.05$.

ss, *,**Nonsignificant or significant by $\mathrm{F}$ test at $P \leq 0.05$ or 0.01 , respectively.

Table 2. Pepper plant lodging as affected by transplant depth during fall and spring in Florida.

\begin{tabular}{|c|c|c|c|c|c|c|c|c|}
\hline \multirow[b]{4}{*}{ Depth } & \multicolumn{8}{|c|}{ Plants lodged $(\%)$} \\
\hline & \multicolumn{5}{|c|}{ Jupiter bell pepper } & \multirow{2}{*}{\multicolumn{3}{|c|}{$\begin{array}{r}\text { Mitla jalapeno pepper } \\
\text { WAT (Spring 1997) } \\
\end{array}$}} \\
\hline & \multicolumn{3}{|c|}{ WAT $^{2}$ (Spring 1992) } & \multicolumn{2}{|c|}{ WAT (Fall 1992) } & & & \\
\hline & 4 & 5 & 6 & 3 & 4 & 5 & 6 & 7 \\
\hline Rootball & $10.4 \mathrm{a}^{\mathrm{y}}$ & $35.4 \mathrm{a}$ & $46.7 \mathrm{a}$ & $11.3 \mathrm{a}$ & $15.4 \mathrm{a}$ & $39.3 \mathrm{a}$ & $44.3 \mathrm{a}$ & $51.0 \mathrm{a}$ \\
\hline Cotyledon & $0.0 \mathrm{~b}$ & $2.9 \mathrm{~b}$ & $2.1 \mathrm{~b}$ & $0.4 \mathrm{~b}$ & $0.8 \mathrm{~b}$ & $0.2 \mathrm{~b}$ & $0.7 \mathrm{~b}$ & $0.7 \mathrm{~b}$ \\
\hline True Leaf & $0.0 \mathrm{~b}$ & $0.0 \mathrm{~b}$ & $0.0 \mathrm{~b}$ & $0.0 \mathrm{~b}$ & $0.0 \mathrm{~b}$ & $0.0 \mathrm{~b}$ & $0.0 \mathrm{~b}$ & $0.0 \mathrm{~b}$ \\
\hline Significance & $*$ & $* *$ & $* *$ & $* *$ & $* *$ & $* *$ & $*$ & $*$ \\
\hline
\end{tabular}

${ }^{2}$ Weeks after tranplanting.

${ }^{y}$ Mean separation within columns by Duncan's multiple range test at $P \leq 0.05$.

${ }^{*}, * *$ Significant by $\mathrm{F}$ test at $P \leq 0.05$ or 0.01 , respectively.

Table 3. Temperature readings taken at 1:00 PM on selected dates in 1995 and 1996 for three soil depths corresponding to the appropriate depths of the rootball for the three transplant depths.

\begin{tabular}{lccccc}
\hline \hline & \multicolumn{3}{c}{1995} & \multicolumn{2}{c}{1996} \\
\cline { 2 - 6 } Depth $(\mathrm{cm})$ & 9 Aug. $^{\mathrm{z}}$ & 13 Aug. & 19 June $^{\mathrm{x}}$ & 21 June $^{\mathrm{w}}$ & $1 \mathrm{July}^{\mathrm{v}}$ \\
\hline 2 & 33 & 40 & 22 & 26 & 27 \\
7 & 23 & 35 & 22 & 23 & 24 \\
12 & 19 & 30 & 22 & 21 & 22 \\
\hline
\end{tabular}

${ }^{\mathrm{z}} 0 \%$ cloud cover, $28^{\circ} \mathrm{C}$ ambient temperature

${ }^{y} 0 \%$ cloud cover, $31^{\circ} \mathrm{C}$ ambient temperature

${ }^{\mathrm{x}} 100 \%$ cloud cover, $18^{\circ} \mathrm{C}$ ambient temperature.

${ }^{w} 50 \%$ cloud cover, $27^{\circ} \mathrm{C}$ ambient temperature.

${ }^{v} 0 \%$ cloud cover, $30^{\circ} \mathrm{C}$ ambient temperature. 
more of the plants' vertical axis (stem) may be physically supported by the soil the deeper the plant is buried. This makes tipping from the base less likely.

Given the consistent results observed in two extremely different growing conditions (Massachusetts and Florida), we recommend that growers transplant pepper seedlings relatively deeper (at least to the cotyledon leaves) to reduce lodging.

\section{Literature Cited}

Cooksey, J.R., B.A. Kahn, and J.E. Motes. 1994 Plant morphology and yield of paprika pepper in response to method of stand establishment. HortScience 29:1282-1284.

Hanna, H.Y., E.P. Millhollon, J.K. Herrick, and C.L. Fletcher. 1997. Increased yield of heattolerant tomatoes with deep transplanting, morning irrigation, and white mulch. HortScience 32:224-226.

Kahn, B.A. 1985. Characterization of lodging differences in paprika pepper. HortScience 20:207-209.

McCullough, M.D., J.E. Motes, and B.A. Kahn. 1995. Soil bedding treatments improve pepper plant anchorage. HortScience 30:1202-1204.

McMichael, B.L. and J.J. Burke. 1998. Soil temperature and root growth. HortScience 33:947-951.
Pinthus, M.J. 1967. Spread of the root system as an indicator for evaluating lodging resistance of wheat. Crop Sci. 7:107-110.

Stoffella, P.J., R.F. Sandsted, R.W. Zobel, and W.L. Hymes. 1979. Root characteristics of black beans. I. Relationship of root size to lodging and seed yield. Crop Sci. 19:823826.

Vavrina, C.S., S.M. Olson, P.R. Gilreath, and M.L. Lamberts. 1996. Transplant depth influences tomato yield and maturity. HortScience 31:190192.

Vavrina, C.S., K.D. Shuler, and P.R. Gilreath. 1994. Evaluating the impact of transplanting depth on bell pepper growth and yield. HortScience 29:1133-1135. 